\section{L'IRIDE ITALIANA: italianidade no Brasil oitocentista}

L'Iride Italiana: Italianity in the nineteenth-century Brazil
Gisele Batista da SILVA

(1) giselebatista@letras.ufrj.br

Universidade Federal

do Rio de Janeiro

Rio de Janeiro, RJ, Brasil

\section{RESUMO}

Este artigo apresenta análises iniciais do periódico bilíngue L'Iride Italiana, fundado no Rio de Janeiro em 1854 pelo poeta e professor italiano Alessandro Galleano Ravara. Pretendese analisar os valores histórico e discursivo presentes em seu projeto ideológico, o qual encena um patrimônio cultural simbólico, compartilhado com o público leitor, a fim de criar uma imagem identitária dos italianos em território brasileiro - a italianidade.

Palavras-chave: Italianidade, Imprensa de imigração, Cultura italiana, Brasil oitocentista.

\begin{abstract}
This paper presents initial studies on the bilingual newspaper L'Iride Italiana, founded in Rio de Janeiro in 1854 by the Italian poet and professor Alessandro Galleano Ravara. It is intended to analyze its historical and discursive values present in its ideological project, which embodies a cultural symbolic heritage shared amongst its readers, in order to create an identity image of the Italians in Brazilian territory - the concept of Italianity.
\end{abstract}

Keywords: Italianity, Immigration Press, Italian culture, Nineteenth Century Brazil. 
Com o novo ano vai continuar (ou já continuou) a ser publicado um lindo jornal italiano e portuguez, do habil professor Galleano Ravara. Já prevejo com que prazer acolhereis a Iride, que, como uma boa mensageira, irá fallar-vos a doce e rica linguagem do Tasso, do Dante e de Petrarca, e recordar-vos aquellas magicas palavras de Romeu e Julieta, quando ouvião cantar o rouxinol e a cotovia ao raiar da alvorada.

José de Alencar

osé de Alencar, em crônica escrita no Correio Mercantil, datada de 7-8 de janeiro de 1855 , confirmava uma rica aliança cultural desenvolvida em terras brasileiras a partir da segunda metade do século XIX. A língua, a literatura e o "nosso teatro italiano", como assim se referia o escritor brasileiro às contínuas encenações líricas que aconteciam no Theatro Lyrico Fluminense e no Imperial Theatro de São Pedro de Alcântara, representaram nesse período mais do que a expressão de uma cultura estrangeira e de imigrantes, uma vez que as diferentes tentativas de incorporá-la à realidade e aos hábitos brasileiros expressaram o esforço de um projeto mais complexo de associação cultural e social entre Brasil e Itália - Alencar referiu-se no trecho a uma dessas experiências, o periódico L'Iride Italiana, Giornale Settimanale del Prof. A. Galleano Ravara, publicação hebdomadária surgida em 1854 no Rio de Janeiro, cuja atuação e recepção ora analisaremos.

Antes mesmo que uma imprensa de imigrantes italianos assumisse um forte papel divulgador da identidade nacional de seus compatriotas - que entre os séculos XIX e XX elegeram as páginas tipografadas para informar, nobilitar ou denunciar matérias políticas, culturais e sociais do país de origem -, a cultura italiana já se afirmava de forma expressiva na capital do Império brasileiro. Indubitavelmente, o casamento de D. Pedro II com Teresa Cristina de Bourbon, princesa do Reino das Duas Sicílias, também conhecido como Reino de Nápoles, foi evento fundamental nesse processo de aclimatação cultural. O matrimônio, ocorrido por procuração em Nápoles no dia 30 de maio de 1843 , concretizou-se com a chegada ao Rio de Janeiro da fragata Constituição, pouco mais de três meses depois da cerimônia formal na Itália, trazendo a imperatriz e seu interesse pela literatura e música italianas, além de sua paixão pela arqueologia (SCHWARCZ, 1998, p. 94).

A "mãe dos brasileiros", como ficou aqui conhecida D. Teresa Cristina, possibilitou que a partir de 1845 se facilitasse a vinda de imigrantes italianos, principalmente médicos, engenheiros, professores, farmacêuticos, enfermeiras, artistas, artesãos - enfim, toda sorte de trabalhadores qualificados, entre os quais muitos se fixaram na Corte. Também não foram esquecidos os trabalhadores braçais e agricultores, homens de discreta cultura formal que, somados aos mais abastados, totalizavam 329 famílias no ano de 1847 e constituíam a primeira colônia italiana no interior da capital do Império, denominada Colônia Vallones dos Reados (VANNI, 2000, p. 42), região do atual bairro de Rocha Miranda. O Rio de Janeiro foi o principal porto de desembarque de imigrantes italianos no século XIX, e em 1875 a cidade se confirmava 
como seu principal destino no Brasil, em razão da facilitação de sua entrada, que D. Teresa Cristina conseguira de seu esposo imperador (AVELLA, 2014, passim).

O número sempre crescente de imigrantes italianos no Brasil, que atingiu notável dimensão no final do século XIX, principalmente em São Paulo e no Rio Grande do Sul, teve seu período embrionário na cidade do Rio de Janeiro, como vimos, onde nasceu, consequentemente, a demanda de um público leitor por notícias de seu país de origem. O Brasil foi o país do continente americano que viu surgir o maior número de publicações depois dos Estados Unidos nesse período (TRENTO, 2013, p. 15), concentrando sua fase de maior produção no início do século $X X$, entre 1900 e 1919, embora já na década anterior apresentasse uma contagem significativa de periódicos circulantes no país.

O surgimento de uma imprensa de imigração em língua italiana resultou na distribuição do primeiro periódico dessa natureza no Rio de Janeiro, antes mesmo da primeira gazeta em português, mas de que infelizmente não se tem qualquer exemplar conservado. Por iniciativa de dois frades capuchinhos, Giovan Francesco da Gubbio e Anselmo da Castelvetrano, surgiu La Croce del Sud em 1765. Dele sabe-se apenas que possuía uma pequena seção em língua portuguesa e que versava, muito provavelmente, sobre temas religiosos (TRENTO, 2013, p. 13). Setenta e um anos depois surgiu na Corte La Giovine Italia, uma iniciativa de exilados políticos que chegaram ao Rio de Janeiro pouco antes de Garibaldi, encabeçados por Giovan Battista Cuneo e estimulados pelos ideais político-libertários mazzinianos. Os realizadores dessa segunda iniciativa de imprensa italiana na Corte, o jornalista Luigi Giacomo Rossetti e alguns compatriotas exilados, garantiram o papel de agitadores culturais em espaço estrangeiro, embora escrevessem exclusivamente sobre fatos italianos (TRENTO, 2013, p. 13) ${ }^{1}$. Dessa publicação também não se tem qualquer traço de resguardo material.

Apesar da existência dessas duas publicações, a historiografia convencionou fixar o marco inicial de uma imprensa de imigração italiana oficial, isto é, de ampla circulação na capital do império e de considerável duração (visto que muitas publicações tinham curtíssima vida, na maioria dos casos por falta de recursos financeiros), a partir da publicação do periódico mencionado por José de Alencar em Ao correr da penna, de caráter predominantemente literário-cultural. Seu programa, publicado no primeiro número do jornal, declarava como objetivos cardinais: "rendere facile e comune una lingua che tanto giova a dilettare lo spirito nelle sue armonie"; "fortificare l'amore alle nostre lettere italiane"; "consigliare alcuni miglioramenti nell'educazione" e "osservare da vicino le mancanze a cui va ancora soggetto il teatro lirico, e correggere coll'opinione (...)"2. O editorial do jornal de Alessandro Galleano Ravara excluiu do escopo dominante da publicação análises políticas ou notícias ordinárias sobre a Itália, não obstante seja possível rastrear poucos artigos nesse sentido ao longo de seus números. A matéria do jornal foi bem explicitada no seu programa: a alta literatura italiana, a língua dos literatos e as óperas líricas que se afirmavam progressivamente nos teatros da Corte. Tal projeto fora bem compreendido por José de Alencar: ao referir-se ao jornal e às letras italianas em sua crônica, fez menção ao ouro literário de Torquato Tasso, Dante Alighieri e Francesco Petrarca, sem esquecer as "belas noites do nosso teatro 
italiano". Também Machado de Assis, quase duas décadas mais tarde, dedicou, em uma crônica de 1877, na Illustração Brasileira, elogios a uma atriz e cantora lírica, Augusta Candiani ${ }^{3}$, que havia estreado no palco do Imperial Theatro de São Pedro de Alcântara em 1844 na ópera Norma, de Vicenzo Bellini, e que em 1877 já alcançara prestígio e sucesso na cidade - as crônicas de José de Alencar e Machado de Assis testemunham que a cultura artística italiana se consolidava na Corte.

À diferença da maioria dos jornais em língua italiana publicados durante o período imperial ou no final do século XIX, já na República, L'Iride Italiana não explorou notícias sobre a questão imigratória ou se apresentou como um suporte exclusivo para imigrados italianos. Aquelas publicações possuíam um caráter mais enciclopédico, tratavam de política, ciências, artes, letras, comércio, indústria e teatro em um só periódico ${ }^{4}$, a fim de informar e de ser um veículo de assistência aos compatriotas imigrados. Já o jornal de Alessandro Galleano Ravara inaugurou o serviço, como definiu Alencar, de "boa mensageira" de uma cultura que ganhava cada vez mais espaço nos circuitos artísticos do Rio de Janeiro da segunda metade do século XIX, buscando substituir, em alguns quesitos, o prestígio de que a cultura francesa ${ }^{5}$ gozava naquele período, seja nos costumes ou na cultura propagada na Corte.

Chama a atenção o fato de que a publicação de Galleano Ravara conste em quase todos os textos e manuais sobre imprensa estrangeira no Brasil, mas não tenha ganhado qualquer estudo detalhado de seu conteúdo e repercussão no Brasil, nem mesmo de seu protagonista, um italiano que permaneceu apenas 17 meses em território brasileiro, mas que cativou desde elogios de literatos brasileiros (como atesta a crônica de Alencar) ao mecenato do Imperador D. Pedro II.

Alessandro Galleano Ravara, professor e poeta nascido em 1820 em San Pier d'Arena, Gênova, foi personagem bastante atuante no cenário de imigrantes italianos na Corte durante parte da década de 1850. Chegado ao Brasil em janeiro de 1854, já havia visitado diversos países, entre os quais Rússia, França, Inglaterra, Suíça, Turquia e Espanha, viagens que começou a interprender aos 20 anos de idade, depois de sua formação superior na Università di Genova ${ }^{6}$. Em Portugal, permaneceu por alguns anos, produziu o Album Italo-Portuguez, antologia que recolheu textos de autores italianos e portugueses, na grande maioria devidamente traduzidos, e em terras lusitanas escreveu ainda uma poesia fúnebre, em 1852, na Revista Universal Lisboense, em memória da falecida princesa D. Maria Amelia (BRANCO, 1895, p. 168). Apenas dois meses depois de sua chegada ao Brasil, já figurava em diferentes jornais brasileiros (Correio Mercatil, Jornal do Commercio, Diario do Rio de Janeiro, entre outros), anunciando seu serviço como professor de línguas estrangeiras "vivas" - italiano, francês e inglês (Figura 1).

Ainda em março auxiliou o diretor a fundar o Collegio de Bemfica, onde também ministrou aulas de inglês, italiano, francês, história e geografia7; iniciou uma série de conferências no Collegio Sr. Zaluar para apresentar seu inovador método de ensino de línguas estrangeiras (baseado no Methodo Portuguez de leitura repentina de António Feliciano de Castilho); e, finalmente, no dia 2 de julho de 1854 publicou o primeiro número de L'Iride Italiana, sob os auspícios de D. Pedro II. No período de apenas seis 


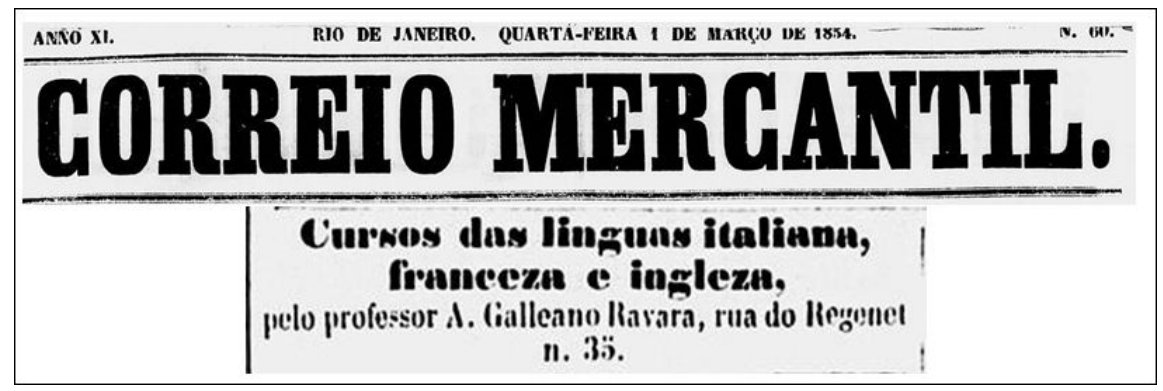

Figura 1: Anúncio de Alessandro Galleano Ravara

Fonte: Correio Mercantil, ano XI, n. 60, de 1\%/03/1854, p. 4

meses, estabeleceu-se na vida intelectual e artística da Corte, recebendo inúmeros elogios na imprensa por sua erudição e dedicação à difusão das letras e das artes em geral. Ao período de Galleano Ravara no Brasil acrescenta-se, ainda, sua atuação no Imperial Collegio de Pedro Segundo: em novembro de 1854, por indicação do Conselheiro de Estado e Ministro da Instrução primária e secundária do Município, substituiu o falecido professor José Manoel Valdez y Palacios nas aulas de inglês ${ }^{8}$ para só posteriormente, em 1855, assumir a cadeira de língua italiana do colégio (Figura 2).

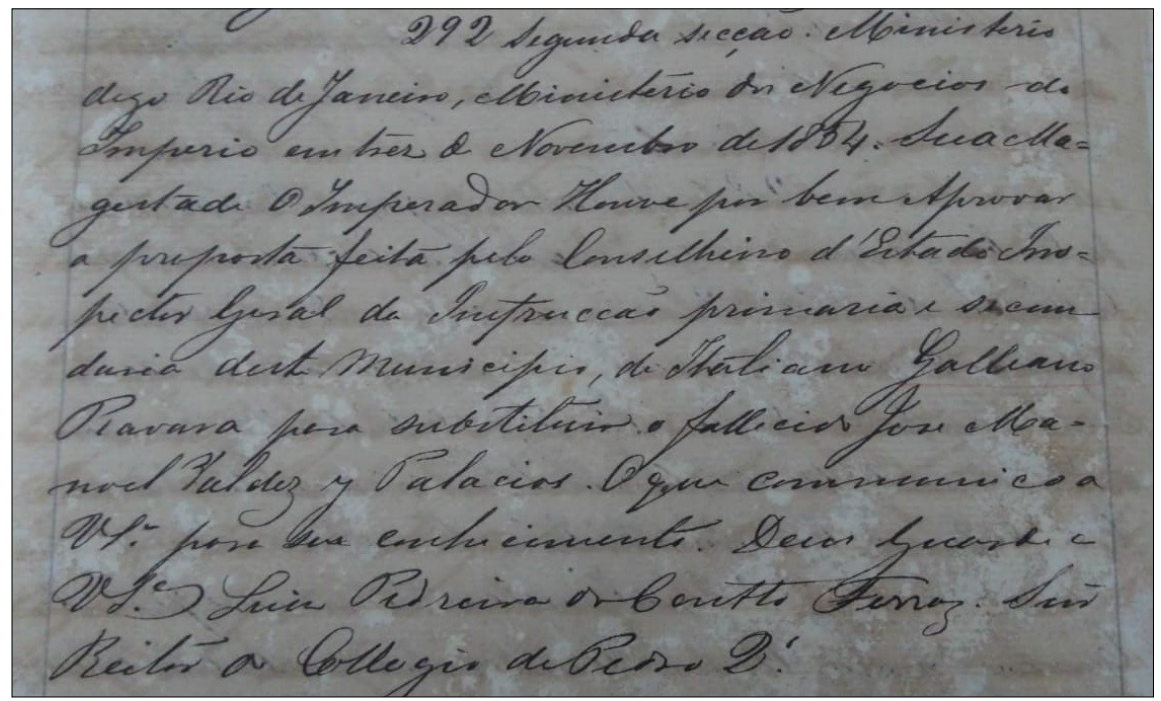

Figura 2: Nomeação de Alessandro Galleano Ravara como professor do Colégio Pedro II Fonte: Livro segundo do Registro dos Officios dirigidos pelo Reitor do Imperial Collegio de Pedro Segundo ao Maximo e Excelentíssimo Senhor Ministro e Secretario d’Estado dos Negocios do Imperio. Período: 1846-1858. 
O jornal de Galleano Ravara, L'Iride Italiana, embora tenha tido breve circulação (de 1854 a 1856) e tenha sofrido algumas interrupções de publicação, uma delas em razão do falecimento de seu fundador em maio de 1855 , foi um veículo de efetivo fomento às letras e à música italiana no Rio de Janeiro, no momento em que na própria Itália ainda se discutia intensamente a unificação nacional e, consequentemente, que língua e literatura representariam a identidade italiana, dentro e fora de seu território. Lembremos que quase quarenta anos antes, em janeiro de 1816, quando a escritora francesa Madame De Staël escreveu o artigo "De la manière de traduire, et de l'utilité des traductions" (1975 [1816]), traduzido e publicado no mesmo mês pelo literato Pietro Giordani na revista milanesa Biblioteca Italiana, o tema da renovação artístico-literária italiana suscitou entusiástica polêmica, presente em diferentes revistas, e envolveu vivamente os intelectuais italianos. O conteúdo do artigo não se limitava a manifestar, como possa sugerir seu título, um elogio à prática tradutória de textos ditos "modernos", mas declarou também o atraso, empobrecimento e certa esterilidade da cultura literária italiana, que insistia em adotar uma postura de permanente recuperação e reprodução de modelos clássicos, cujos padrões, segundo De Staël, já haviam sido reavaliados e substituídos em diversos países europeus, por meio do contato intelectual com textos estrangeiros traduzidos. Tal artigo gerou uma conhecida e importante querela em revistas e salões literários italianos, dividindo seus intelectuais entre aqueles de concepção mais conservadora e outros de perspectiva mais progressista, isto é, romântica. É evidente que o artigo da escritora francesa abria ainda mais a ferida histórica italiana: a sua crítica parecia proclamar, na prática, um território sem nação e sem literatura e cultura modernas próprias.

Nota-se que na publicação de Alessandro Galleano Ravara, entretanto - e mesmo tantos anos depois da polêmica gerada pelo artigo de De Staël, mas cujos reflexos se faziam ainda sentir na Itália -, os polêmicos temas da unificação ou da carência cultural italiana não parecem obstaculizar o cultivo de uma imagem de italianidade no Rio de Janeiro, isto é, de uma representação de coletividade "nacional", de um patrimônio cultural simbólico e discursivo, por meio do desejo declarado de coesão e propagação da língua e da matéria artística italiana como objetivos precípuos do jornal. De fato, Alessandro Galleano Ravara esclarece que "Em um país estrangeiro, onde se sabe que existe uma Itália no mapa, mas onde todos não sabem como ela é dividida, onde todos não sabem que Genovês e Piemontês, Napolitano e Romano, Parmense e Luquês, Fiorentino e Bolonhês sempre significa italiano" 9 : embora um sentimento de unidade ainda fosse um discurso aquém da realidade concreta e limitado a específicas classes sociais, seja na Itália ou no Brasil, L'Iride parece desempenhar o papel de circunscrição empírica que alimentava tal sentimento e que, consequentemente, forjava e chancelava a existência de uma nação italiana, pelo menos em território estrangeiro.

O programa do jornal falava aos leitores sobre a situação político-geográfica fragmentária da Itália no século XIX, ao mesmo tempo em que parecia assumir engajamento na ideia de fraternidade e comunhão. Se tal comentário refletia um posicionamento político risorgimentale mazziniano do locutor do jornal, ainda é cedo para afirmá-lo. Certa é a produção de um discurso que simula coparticipação, 
conectado a um sentimento de congraçamento e congeneridade com compatriotas e também com brasileiros (por meio da concepção de "línguas irmãs", a italiana e a portuguesa), a fim de contestar a imagem do que se considerava, no Brasil, formador do imaginário social e cultural italiano. A própria crônica de José de Alencar, antes mencionada, mostra como a Itália entrava no Brasil também por canais ilegítimos, com a citada obra de Shakespeare, Romeu e Julieta, que alude a um imaginário, mas não é uma expressão direta da literatura e da cultura italiana. A confirmar nossa especulação, exprime ainda o programa de L'Iride: "A quem escreve e fala de teatro não é suficiente saber solfejar a expressão do tenor [...], mas sim [...] ser italiano, pelo menos sentir como um italiano, falar como um italiano, compreender como os Italianos"10 - segundo o jornal, havia uma singularidade "italiana" (linguística, social, cultural) desconhecida em solo brasileiro e cuja deficiência o jornal se propunha a suprir, justificando a necessidade de sua existência ${ }^{11}$. Do ponto de vista linguístico, tal propriedade se afirmava por meio da variedade da língua italiana que o jornal veiculava, a qual, entretanto, não era de largo domínio entre italianos. Na década de 1860, logo após a unificação, e mesmo depois, até o final do século, o número de italófonos variava de $2,5 \%$ a $9,5 \%$ da população, isto é, a parte da população que falava a variante literária florentina era muito pequena e se concentrava em classes sociais abastadas (DE MAURO, 1991, p. 36; CASTELLANI, 1982). O resto da península se resumia aos mais de $90 \%$ de analfabetos, homens e mulheres que se comunicavam por meio de seus dialetais regionais. Já no Brasil Galleano Ravara ignorou, em sua L'Iride, esses traços sociolinguísticos ou mesmo os constantes debates entre intelectuais italianos sobre a questione della lingua, ocultando a situação de bilinguismo e diglossia dominante em todo território italiano. Na Itália de Ravara no Brasil - a sua L'Iride -, a variante fiorentina, da literatura e do teatro, era a única manifestação linguística que representava a cultura italiana.

Mas o que era, então, considerado “constitutivamente italiano" por L'Iride? Como pensar, sentir ou compreender como um italiano? Qual imagem de italianidade desejava construir o jornal? A proposta do periódico parece tentar demarcar esses movediços conceitos, reinventados e ressignificados por diferentes grupos, segundo diferentes interesses, possivelmente motivada por ideologias nacionalistas, largamente difundidas na Itália do século XIX. Essa aspiração, sem dúvida, servia-se de um complexo aparato discursivo para dar legitimidade ao imaginário identitário que desejava sigilar. No primeiro número de L'Iride Italiana, os baluartes da italianidade, os quais "possibilitavam" ser, sentir, falar e compreender o teatro lírico "como um italiano", revelavam-se por meio do valor e da relevância da língua (representada pela literatura e pelo canto lírico), conquanto ela se encontrasse exposta, segundo o jornal, ao abandono e à indiferença - "Oh pobre escrava da tua beleza e dos teus encantos! Por que te arrastas no pó e não te ajoelhas para implorar a Deus por tua pessoa?"12. Recuperar e revalorizar a língua era, no jornal de Galleano Ravara, exercício fundamental para alicerçar e fortalecer o sentimento nacional.

Embora "Carattere e fine principale di questo giornale" (uma continuação, no segundo número, do editorial apresentado em 2 de julho de 1854) não tenha exibido a explícita assinatura de Galleano Ravara, sabe-se que o jornal apresentou-se como um 
suporte autoral (com o subtítulo "Giornale settimanale del Prof. A. Galleano Ravara") e que, portanto, grande parte de seu espaço discursivo fora ocupado por matérias exclusivas do fundador (mesmo na seleção de textos da literatura italiana), salvo algumas contribuições de outros personagens da vida pública da Corte, entre brasileiros e italianos. Sua voz, como fala e corporalidade ${ }^{13}$ ilustrativas da cultura italiana no jornal, pretendia equivaler a diferentes vozes de "italianos", os quais buscavam formas de expressão e de representatividade no Brasil, segundo afirma algumas vezes a própria publicação de Galleano Ravara: "Fala italiano, onde você vai; versa o doce sim da tua Península no ventre da irmã que ela ama"14.

No universo tipográfico brasileiro, a maior surpresa ficou reservada ao caso italiano, cuja proliferação de jornais ganhou proporções inimagináveis, de forma correspondente à presença e à atuação de imigrantes no país. L'Iride Italiana foi precursora nesse processo em diferentes aspectos: foi o primeiro incentivo concreto da imprensa de imigração de cooperação cultural entre Brasil e Itália, com a chancela e o apoio pecuniário do Imperador do Brasil; publicou o primeiro folhetim em imprensa de língua italiana ${ }^{15}$; e, finalmente, seguiu a tendência de jornais bilíngues da época, dirigindo-se a compatriotas, mas - nota-se no seu caso - principalmente a brasileiros: a seção "Metodo Pratico per imparare la lingua Italiana" [Método prático para aprender a língua italiana] põe-se como serviço pedagógico de divulgação do método criado por Galleano Ravara, amplamente anunciado em periódicos da época, para aprendizagem da língua italiana por estrangeiros. Tal seção do jornal parece propor-se como extensão das salas de aula de Ravara, uma espécie de manual didático da língua italiana como instrumento de conhecimento da língua e da cultura da península europeia (Figura 3).

A primeira preocupação do jornal parece ter sido, portanto, a conquista de leitores amantes das letras e da cultura italiana que desejassem aprender ou aprimorar sua erudição. Contrariando uma tendência de dispositivo integrador do proletariado que predominou na imprensa estrangeira italiana no Brasil de fins do século XIX e início do $\mathrm{XX}$, L'ride Italiana foi exemplo de uma imprensa erudita e cujo grau de especialização temática voltou-se exclusivamente para conteúdos sobre língua, literatura e teatro lírico - Galleano Ravara o denominava "giornale litterario teatrale"16.

Algumas atribuições do jornal ficam claras ao percorrer suas páginas. Seu incontestável papel pedagógico apresenta-se sob três aspectos: o primeiro, e mais evidente, expressa a divulgação da língua italiana, por meio do método didático de Galleano Ravara, que elucida aspectos fonéticos, conversacionais, proverbiais e tradutórios do italiano. O segundo aspecto, mais argucioso, diz respeito à domesticação do gosto e do estilo em matéria cultural italiana, na medida em que era publicado e traduzido no jornal aquilo que o locutor considerava o cânone da literatura italiana. No primeiro número do jornal, por exemplo, o texto original do canto I do Inferno da Commedia de Dante, de quem Galleano Ravara era grande admirador ${ }^{17}$, é integralmente apresentado com a sua tradução ao lado. Excluem-se desse quesito os folhetins, que divulgavam ora poesias do próprio fundador do jornal, ora trechos de obras literárias italianas (como é o caso de Margherita Pusterla, de Cesare Cantù, ou o prólogo às Sátiras alfierianas, Il Cavalier servente veterano). Ainda sobre o mesmo aspecto, o 


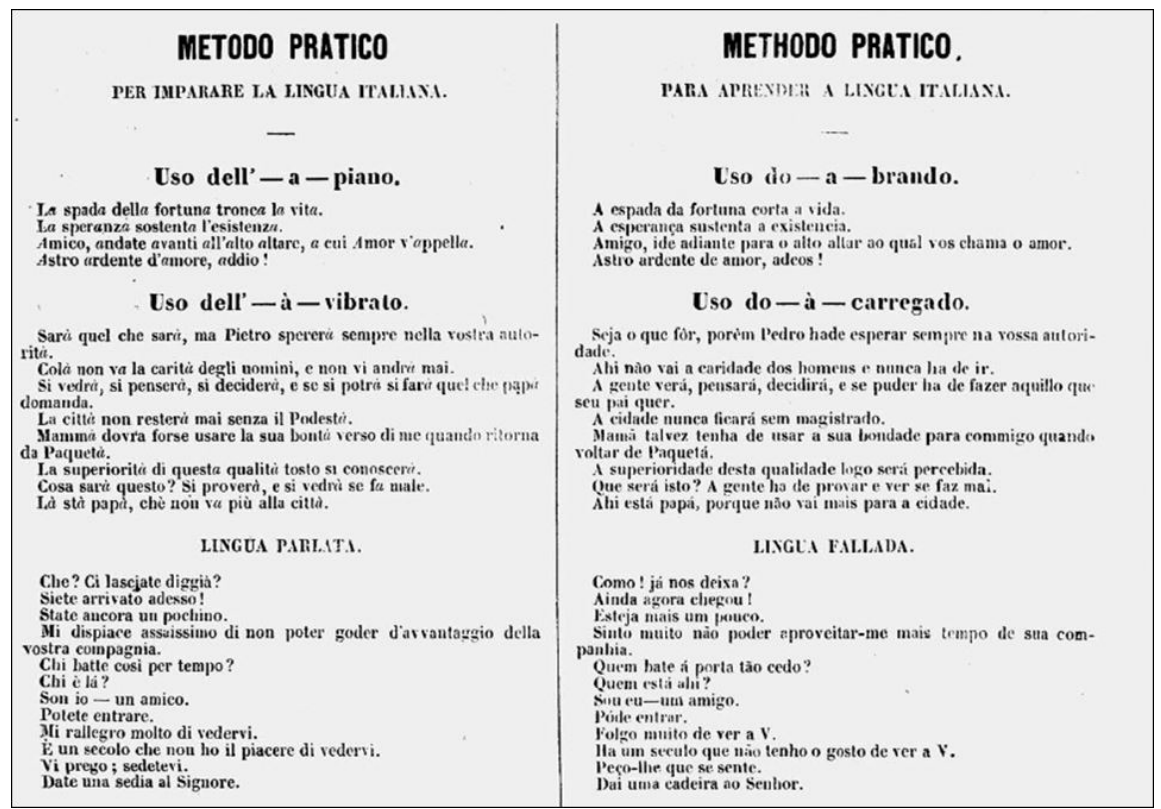

Figura 3: Coluna "Metodo pratico per imparare la lingua italiana”, publicada em 23 de julho de 1854

Fonte: L'Iride Italiana, 23/07/1864

periódico propunha-se a corrigir os vícios do "infausto" teatro lírico ou a enaltecer aqueles de elevada qualidade: a coluna "Teatro Lirico Fluminense" apareceu pela primeira vez no terceiro número do jornal, em 16 de julho de 1854, esclarecendo que não aspirava "à conquista de corações teatrais" e que a sua pena era pacífica, afirmação que não elimina seu papel docilizador, dadas as críticas que fazia a atores e montagens teatrais. O último aspecto, finalmente, refere-se à salvaguarda de uma memória que era, contemporaneamente, forjada e evocada por meio da construção de uma imagem coletiva representativa - marcada pelos recursos discursivos utilizados para a sua concretização no jornal.

Parece-nos evidente que esse empenho pedagógico dedicava-se à formação de uma imagem de italianidade pelo jornal em questão, cujo objetivo era "fazer os italianos" em terra estrangeira, sancionando um conhecimento sobre sua cultura. Em um momento fulcral de intensas querelas e questionamentos políticos, sociais, linguísticos e culturais na Itália, parecia ser muito mais simples buscar formas de afirmação nacional no Brasil do que no país de origem. De fato, foi criado ao longo do século XIX um considerável número de instituições no Brasil que objetivavam tecer relações sociais de convívio e concórdia entre italianos, conforme o processo de imigração de italianos crescia no Brasil. Até 1870, o Rio de Janeiro ganhou maior 
número dessas instituições, posto que a grande maioria dos veleiros provenientes da Itália atracava na Baía de Guanabara, e aos imigrantes recém-chegados era imposto um período de quarentena em uma hospedaria na Ilha das Flores, hodierna região de São Gonçalo (AVELLA, 2010, s/p). É o caso da Società Italiana di Beneficenza e Mutuo Soccorso, fundada em 1854, que recebeu a consistente contribuição de 400 contos de réis de D. Pedro II (CAPPELLI, 2015, p. 24); do Centro d'Istruzione, criado em 1896 pelo viajante Pietro Antonelli e pelo farmacêutico Nicola Alotti (VANNI, 2000, p. 85-86); e, claro, da própria imprensa em língua italiana que, com a precursora L'Iride Italiana, recebeu patrocínio do imperador, mantendo a regularidade de sua publicação. Ela funcionou como importante dispositivo de interlocução e divulgação desse projeto identitário, cuja imagem, uma operação de idealização do espírito, tinha por objetivo forjar um conceito, uma ideia capaz de explicar uma totalidade, dando-Ihe fundamento e sentido.

Ao que tudo indica, L'Iride Italiana não visava estabelecer-se como lugar "entre" origem e realidade de imigração, ou ser uma ponte interlocutória entre notícias da Itália e a nostalgia dos imigrados, mas sobretudo idear um sentimento comum de pertencimento a um sistema de valores simbólicos peculiares e de alto padrão, como demonstra o trecho a seguir, retirado do editorial de L'Iride, publicado em 9 de julho de 1854:

Não - não! Outra vez não! - Que um inglês seja legislador ou
comerciante, o alemão beba e fume cachimbo, o francês recite a
comédia e o italiano cante!... Pena que esta única glória que nos
resta não tenha o valor dos troféus de Camilo e de Augusto! Mas
é nossa propriedade... é a nossa glória! - única, mas grande!...
única, mas encantadora!... única, mas inalienável!18

Os domínios culturais e de costumes estão bem determinados no trecho, uma vez que a cada nacionalidade são atribuídos um valor e uma autoridade. Na passagem, mesmo sem a justa e merecida relevância, apenas os italianos detinham a supremacia do canto lírico, a eles pertenciam as glórias alcançadas e deles viriam as melhores e mais adequadas críticas ao aperfeiçoamento desta arte. A erudição nas letras parece ser o fio condutor dessa idiossincrasia coletiva dos italianos no periódico, que elevava qualquer empenho nesse campo à excelência de suas produções artísticas.

De L'Iride Italiana, Giornale Settimanale del Prof. A. Galleano-Ravara é possível recuperar na Hemeroteca Digital da Biblioteca Nacional, 34 números publicados, distribuídos, confome o Quadro 1.

O preço do jornal sofreu algumas alterações ao longo desses anos de publicação, tanto no valor como nas modalidades de adesão. Em 1854, o leitor podia pagar pelo número individual ou fazer a assinatura trimestral ou anual. Pela primeira modalidade eram cobrados 500 réis, pela segunda $3 \$ 000$ réis e finalmente pela terceira $10 \$ 000$ réis; nos dois últimos casos o pagamento era antecipado. Ao longo de 1855, notamse algumas variações nesses valores e na forma de subscrição: até o número 15, isto é, quando a morte do fundador Alessandro Galleano Ravara é anunciada, eram 
Quadro 1: Exemplares de L’Iride Italiana disponíveis na Biblioteca Nacional

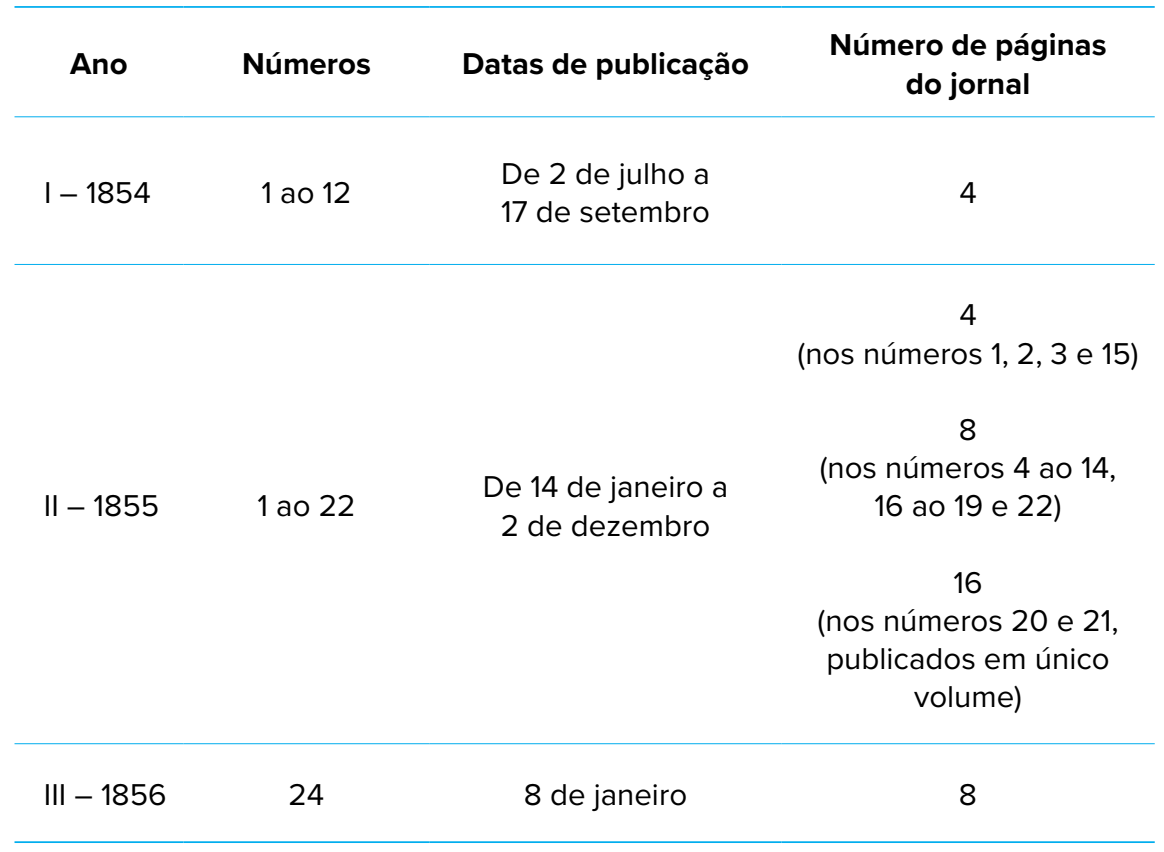

Fonte: Hemeroteca Digital, Biblioteca Nacional

divulgados apenas os valores trimestral e anual, que se mantiveram os mesmos de 1854, pagos antecipadamente. A partir do número 16, com o jornal sob a nova direção de Pietro Bosisio, e até o último número publicado em 1856, o periódico continua com o pagamento antecipado, mas com novos valores: "Corte e Nietherohy $5 \cup 000$ / Provincias e Exterior 6 U000 / Um numero avulso U500 / Annuncios, publicações a pedido 80 reis cada linha".

Nossa análise se concentrou mais detidamente nos números publicados pelo fundador Ravara - e, portanto, dedicou-se aos números de 1854 até o número 14 de 1855. Ainda que as seções e colunas do jornal fossem escritas, em sua maioria, pelo poeta e professor italiano (com assinaturas do tipo "R." ou "A. G. Ravara" ou, ainda, "A. Galleano-Ravara" ou mesmo sem elas), outras figuras do convívio de Galleano Ravara, em Portugal ou na Corte do Rio de Janeiro, participaram dessa empreitada jornalística. Por um lado, algumas assinaturas (de textos inéditos ou traduções) falam pouco de seus personagens e requerem análise e estudo mais detalhado, como as iniciais “B. T.”, “B. F. C. S.”, “C. S.”, “Z. X.”, G. B. T.”, “C. B. T.”, “G. M.”, “G. X. B.”, “X”; outras dão indicações genéricas ou são pseudônimos, como "Aurélio", "Almeida”, "Silva”, "Fra Morsego" ou "La Verità". Há, entretanto, casos com assinaturas mais explícitas: traduções de José Maria Latino Coelho (“J. M. Latino Coelho”), de Justiniano José 
da Rocha (“J. J. da Rocha”) e do médico italiano Luigi Vincenzo De Simoni ("L. V. DeSimoni”, “L. V. D. S.”); textos de Antonio Bordo (“A. Bordo”) e António Feliciano de Castilho, poemas escritos por Ravara, com tradução de "Zaluar" (dando indicações da participação de Augusto Emílio Zaluar) ou pelo jovem Fernando Gonçalves Braga, dedicado a Domingos José Gonçalves de Magalhães. De compatriotas atuantes na comunidade italiana presente na Corte temos as contribuições de Dr. Giuseppe Galli, Angelo Marini, Cesare Persiani (presidente da Società di Beneficenza Italiana em 1855), entre outros.

Nas diferentes seções e colunas que publicou no formato vertical do jornal algumas mais regulares, outras menos -, poucas se dedicaram a assuntos que não versassem sobre literatura e teatro, como "Necrologia italiana", "Cose italiane", "Politica”, “Notizie italiane”. Elas não possuíam regularidade nos números consultados (algumas foram publicadas uma única vez), ao contrário das seções "Teatro Lirico Fluminense", "Metodo Pratico per imparare la lingua Italiana", "Sciarada, "Proverbi ed idiotismi", "Poesia" ou "Dizionario biografico italiano" (com a narração da vida de ilustres personalidades italianas ou ligadas à sua cultura), em que a constância marcava o compromisso permanente em alimentar a publicação com informações de natureza artística e literária. Merece destaque a coluna sobre teatro lírico (Figura 4), que aparece em quase todos os números de L'Iride, tendo sido o segmento do periódico mais frequente (mesmo depois do falecimento do fundador do jornal). A forte presença do teatro lírico no Rio de Janeiro demandava um espaço crítico que permitisse acompanhar e compreender aquelas encenações. Como consta no editorial do periódico, L'Iride Italiana colocava-se a serviço dos leitores que buscavam aprofundar seus conhecimentos em matéria artística, cedendo sua voz e autoridade discursiva (na medida em que a coluna era escrita por um italiano) para dar legitimidade à crítica que divulgava.

\section{TBATRO LIRICO PLLYIINEASE.}

MADAMF CHARTON.

In un articolo che per moneanza di spazio non può essere oggi pubblicato, abbiamo dedicato alcune delle nostre parole alla nobile interprete della infelice Scozzese che ispirò tanto l'autorc dell'ultimo canto del bardo. Ne parebbe però disobbedire agl'impulsi della nostra coscienza lasciando scorrere tempo ancora di mezzo il trionfo che l'attrice Francese ha riportato, e l'ovazione che la penna Italiana offre come patto di riconciliazione e d'amore.

ofre come patto di riconciliazione e d'amore.
L'Italia terra soggetta alle invasioni d'ogni specie ha veduto in Litalia terra soggetta alle invasioni dogni specie ha veduto in
questi ultimi tempi oceupato anche il suo unico seggio musicale. Austria, Francia, Inghilterra l'hanno presa d'assalto, e agl interventi armati, ai protettorati, agli amori politici s'aggiunsevo gl'interventi musicali ; si trapiantò il lauro d'Italia forse? quella pianta della gloria e dell'arte non fruttifica che là NEL BEL PAESE CHE APPENIN PATT

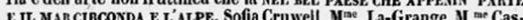
. tellan, M. Chorton, la llayez, eswiftci hanno insegnato a perdonare agl'invasori, ma noi abbiamo lovo imposto delle condizioni. Italianizzatevi! E Cruwell, Charton, Hayez e tutte le celebritá straniere hanno accettato il patto di fratellanza. Tutto non ci fa tolto ancora !
Cioc̀ : abbiamo molto concedulo allo straniero, ma non tutlo.... Era impossibile, se no avenuno commesso anche questo peccato. Ne abbiamo coinmessi dei più gravi!

Benedetta la terra che vi ha prodotta, benedetto il cielo che vi brilli negli occhi quando gli apriste, benedette le mura che hanno udito i! vostro primo vagito.... Ma noi, mille e mille volle niu benedelti che vostro primo vagito.... Ma noi, mille e mille volte piu benedelti che
$n$ è dat d'udire le lagrime della purissima anima vostra, i sospiri mun è dat d'udire le lagrime della purissima
sicali di quel cuore pieno di vita italiana !

Se l'artista che non lascia opere sulla terra dovesse vivere dopo la sua morte, basterebbe ai nostri posteri pronunciare il vostro nome, o Charton, per dare un'idea completa d'un dolcissimo sentimento wusicale, t'une grasia ine fabile di non umana tempera.

La nostra opinione sul vostro merito è questa : : la Charton quando canta fa dimenticare la vita terrena. * Siamo cultori delle Muse, semcanta fa dimenticare la vita terrena. * Siamo cultori delle Muse, sem-
pre tendenti ad usare delle figure poeticho) peró quando si serive cio che si sente, si dice sempre

RIO DE JANEIR0.-TYPOGRAPHIA,-Rua do Cano n. 165.

Figura 4: Coluna "Teatro Lirico Fluminense"

Fonte: L'Iride Italiana, 23/07/1854. 
Do ponto de vista discursivo do jornal, as primeiras e mais evidentes características que apontam a construção dessa italianidade são as referências dêiticas à pessoa que, por um lado, identificavam os participantes da interação comunicativa e, por outro, excluíam coenunciadores que não fossem "convocados" no discurso ou que não correspondessem às descrições informadas. Assim, ao mesmo tempo em que um "nós" inclusivo explicitava uma coletividade, também anunciava uma restrição, uma supressão daqueles que desse universo não faziam parte, como aponta o seguinte trecho: "Com o talento inegável que nós temos para todo tipo de erudição filológica, com as tendências visíveis que possuímos para falar e escrever as línguas mais vulgares e mais úteis da Europa, apenas encontramos hoje um pouco disseminada entre nós a língua francesa"19. O locutor de L'Iride não só mostrava sua adesão à opinião veiculada, mas também exprimia sua apreciação favorável ao conjunto de características a esse grupo designado, excluindo os grupos que não o possuíam. É diferente, portanto, do "nós" utilizado por José de Alencar na passagem da crônica que vimos anteriormente, em que o uso do dêitico em "belas noites do nosso teatro italiano" - não obstante sugira um locutor como sujeito compartilhado - deseja, na verdade, indicar o espaço de enunciação: isto é, o teatro italiano encenado "aqui", no Rio de Janeiro, por italianos que moram na Corte e, por isso, "nosso".

L'ride Italiana, como dissemos, sofre breve interrupção em 1855, após o falecimento do jovem Alessandro Galleano Ravara em 8 de maio, aos 34 anos de idade. O último número do periódico do qual Ravara ainda participara data de 22 de abril, tendo retornado o jornal só um mês depois, em uma publicação dedicada exclusivamente a homenagear seu fundador recém-falecido. Sua morte prematura é publicada em 10 de maio no Correio Mercantil (Figura 5) e, posteriormente, surge também uma série de anúncios que recordam a atuação intelectual do professor italiano na Corte:

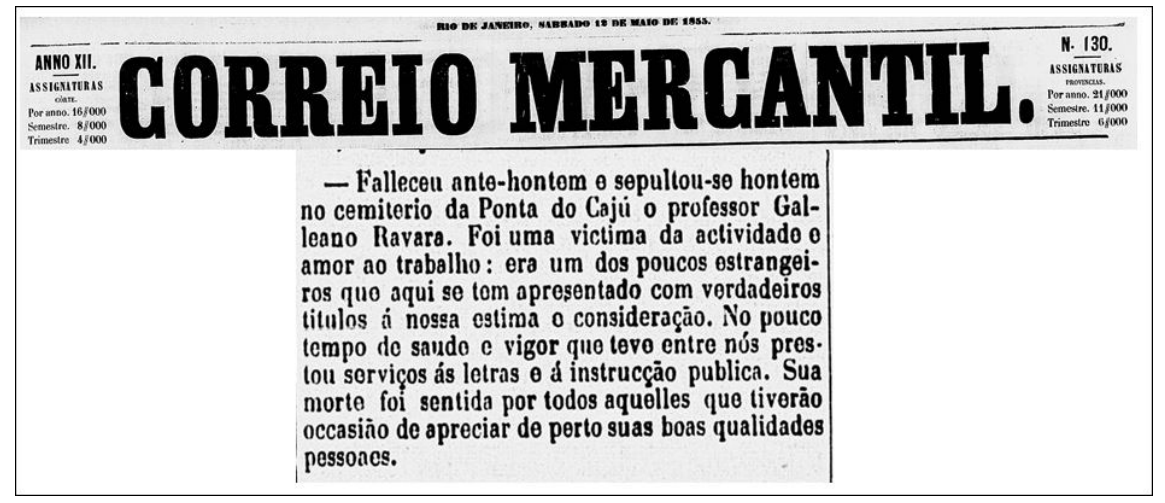

Figura 5: Obituário de Alessandro Galleano Ravara

Fonte: Correio Mercantil, ano XII, n. 130, 10/05/1855, p. 1 
Ou ainda, em 13 de maio, uma semana após a sua morte, o amigo italiano Pietro Bosisio publica no Correio Mercantil um agradecimento às honrarias e aos elogios dirigidos ao amigo recém-falecido, gesto possível devido à "generosa hospitalidade com que os brasileiros acolhem sempre todos os estrangeiros dignos de estima, e que se apresentão munidos de verdadeiros títulos de moralidade e capacidade"20. Finalmente, em 19 de setembro, quatro meses após a morte de Galleano Ravara, Pietro Bosisio decide anunciar no mesmo jornal que assumiria a direção de L'Iride Italiana, informando ainda as inovações que o periódico sofreria: "Publicar-se-ha uma vez por semana, com caricaturas, retratos, vistas, etc". Em 4 de outubro de 1855, ressurgiu finalmente o jornal com novo nome e nova diagramação: Giornale Ebdomadario, Redatto in due lingue, italiana e portoghese; o subtítulo esclarece ainda sua matéria, "Teatri, Belle-Arti, Letteratura, Industria, e Notizie, con illustrazioni, e caricature, disegnate e litografate dal Sig. A. Sisson". Sob nova direção, o jornal herdeiro de L'Iride Italiana tem seu subtítulo modificado, mas mantém os mesmos princípios da linha editorial inicial, resguardando a crítica literária, teatral e musical como fios condutores ao tema cultural italiano, mas agora apresentava também notícias de natureza mais ordinária e de utilidade pública. Não encontramos na imprensa, contudo, a mesma regularidade e entusiasmo dedicados à primeira fase de L'Iride Italiana, cuja propaganda e elogios figuravam constantemente nos periódicos da Corte, e inclusive fora dela. O Diário de Pernambuco, de 22 de dezembro de 1854 (n. 293, p. 4) a $1^{\circ}$ de janeiro de 1855 (n. 22, p. 4), por exemplo, apresentou quase que diariamente informe sobre a possibilidade de subscrição do periódico na cidade, confirmando a sua distribuição fora do Rio de Janeiro.

L'Iride Italiana, revista artistica, scientifica e letteraria, debaixo do immediato patrocínio de S. M. o Imperador, redigida em duas línguas pelas mais conhecidas capacidades do império, e dirigida pelo professor A. Galeano-Ravara. Subscreve-se em Pernambuco, na livraria n. 6 e 8 da praça da Independencia.

Na Corte, diversos são os jornais e revistas que anunciavam L'Iride ou quaisquer outras notícias ligadas ao nome de Galleano Ravara: além do Correio Mercantil e do Jornal do Commercio, também o Diário do Rio de Janeiro, o Almanak Administrativo, Mercantil e Industrial do Rio de Janeiro, O Correio da Tarde, Novo Correio das Modas, O Guanabara, Marmota Fluminense, entre outros. Sobre a nova "versão" de L'Iride, poucos jornais se limitaram a anunciar a boa-nova e é possível notar, em alguns casos, certa insatisfação pelo novo serviço. É o caso da publicação no Jornal do Commercio, n. 320, de 21 de novembro de 1855, portanto pouco mais de um mês após a retomada do periódico por Bosisio: "Roga-se ao IIIm. Sr. Redactor da Iride Italiana o obsequio de fazer observar com mais exactidão a distribuição da sua folha, afim de evitar da sua parte juízo temerario sobre quem reclama contra a irregularidade na entrega desse periodico. Um assignante". A crítica parece referir-se não apenas ao atraso da entrega, mas também à idoneidade da nova direção e, talvez, à própria qualidade do periódico. Ainda no Correio Mercantil, de 21 de julho de 1863 (n 199, p. 2), Galleano Ravara e sua L'Iride Italiana foram relembrados em artigo que homenageava o tenor Arthur 
Gentile, como um dos suportes que prestou importante serviço à cultura do teatro lírico no Rio de Janeiro, e lamentando a então escassez de periódico desse gênero.

Antes da morte de Ravara, vale lembrar, a circulação de L'Iride Italiana já havia sido suspensa: o número 12, publicado em 17 de setembro, fora o último do ano de 1854 e o jornal só retornaria no ano seguinte, em 14 de janeiro. Embora a justificativa oficial para tal suspensão seja desconhecida, é interessante notar que, em 20 de agosto de 1854, o número 8 de L'Iride traz um texto intitulado "Supplica d'un poeta giornalista ad un Cesare" (Figura 6), no qual, o poeta dedica aqueles versos à "Persona Augusta", a fim de realizar "as esperanças de um cavalheiro que não possui outra mania senão propagar a sua língua pelo mundo". O adjetivo "augusta” referia-se claramente ao Imperador do Brasil, a quem aquela poesia foi seguramente dedicada, e o lamento e a súplica contidos nela tornavam-se cada vez mais aflitos e persuasivos ao longo da composição poética, como mostram os trechos abaixo:

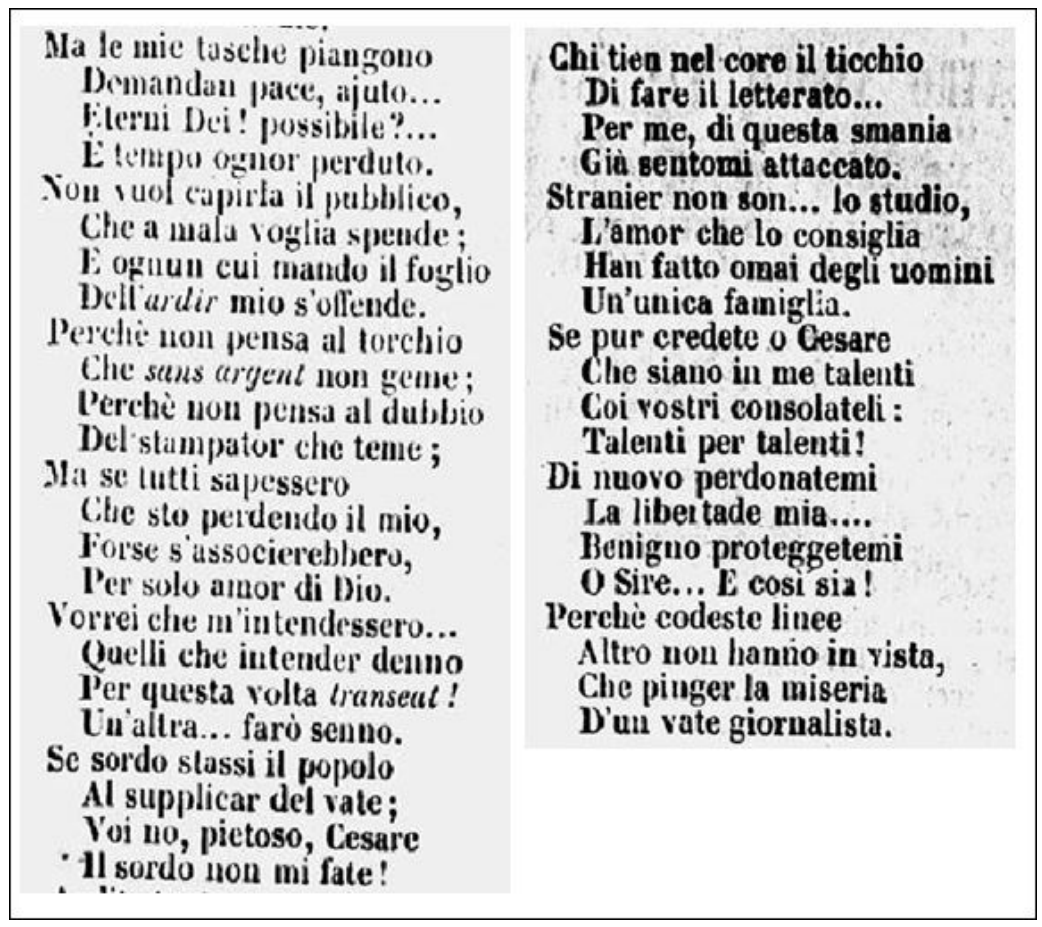

Figura 6: "Supplica d'un poeta giornalista ad un Cesare"

Fonte: L'Iride Italiana, 20/08/1854, p. 2-3. 
"Mas os meus bolsos choram / Demandam paz, ajuda": conquanto não tenha sido assinado, o poema parece narrar a difícil trajetória de Galleano Ravara e de sua L'Iride ('[...] chorar a miséria / d'um vate jornalista) a qual, de fato, poucos números depois sai de circulação por quatro meses. No poema, lamenta-se a falta de assinantes do jornal, a incompreensão do público leitor, que "não imagina a prensa [tipográfica] / que sem dinheiro não geme"21, a desconfiança dos tipógrafos e, finalmente, dirige seu clamor ao piedoso "Cesare", isto é, a D. Pedro II: "Benévolo, protege-me!".

A súplica publicada no jornal tem seus prósperos efeitos para o "vate giornalista" italiano Galleano Ravara: em 14 de janeiro de 1855, L'Iride Italiana retoma a sua publicação, sob novo formato. A fonte usada no título do jornal é modificada, as epígrafes do jornal - que antes continham trechos de Vincenzo da Filicaja, Casimir Delavigne e Thomas Moore (Figura 7) - são reduzidas e apenas o toscano Filicaja é exibido no cabeçalho do jornal: "Fia l'opra istessa il guiderdon dell'opra" [Será a obra mesma a recompensa da obra]: o trecho de "Poesie toscane" faz parte de um poema dedicado à rainha Cristina da Suécia. Após sua conversão ao catolicismo em 1654, Cristina foi para Roma e dedicou-se à proteção e à condução da atividade de diversos artistas, confirmando a inclinação literário-artística do jornal. Além do cabeçalho, a tipografia encarregada em imprimir o jornal havia mudado: antes impressa em tipografia sem indicação de nome, localizada na Rua do Cano 165, a Typographia Americana de José Soares de Pinho passou a se ocupar da reprodução de L'Iride Italiana em $1855^{22}$, fato que parece indicar um aumento das perspectivas pecuniárias do jornal. A confirmar essa hipótese, seria a mais importante mudança na primeira página no jornal ítalo-brasileiro: "Sotto l'immediato patrocinio di S. M. L'Imperatore" [Sob o imediato patrocínio de S. M. o Imperador] - confirmado o auspício do Imperador D. Pedro II, L'Iride garantia a regularidade da publicação e, claro, tinha o prestígio do nome do imperador estampado na primeira página, a sigilar o patronato e a notoriedade de que necessitava o periódico para adquirir o número de assinantes que tanto desejava (Figuras 8 e 9). Entretanto, o ilustre nome nobilitou as páginas do periódico por pouco tempo: com a morte de Galleano Ravara em maio de 1855, o jornal sofre nova interrupção e retorna só em outubro sob a direção de seu amigo e engenheiro milanês Pietro Bosisio (18181881) (Figura 10). O novo redator dava aulas de contabilidade, mas também de língua francesa e italiana. Embora nosso objetivo tenha sido analisar os números do periódico sob a direção de seu fundador, não podemos deixar de mencionar as mudanças sofridas após o falecimento de Galleano Ravara: reconhecida a dificuldade de levar adiante um trabalho de engenhosa e inteligente mente ("Combatido por mil dúvidas, contido pela consciencia de nossos poucos conhecimentos litterarios [...] Conscio da espinhosa defficulddade e dos inevitaveis desgostos que se encontra na publicação de um jornal [...]"23), Bosisio admite a importância da continuidade da publicação para propagação da língua e dos conhecimentos sobre teatro que o jornal sempre desempenhou - "[...] graças ao fecundo germen lançado pelo nosso predecessor e o zelo do augusto monarca [...] tudo isto foi para nos mais do que sufficiente para que, posta de parte toda hesitação nos determinassemos á fazer continuar a publicação do presente jornal" 24 . Os obstáculos que as exigências do tema impunham ao grupo à reintegração do periódico foram vencidos pelos "numerosos pedidos que com 
instancea nos tem feito muitos artistas e correspondentes italianos da Europa"25 músicos, atores e intérpretes que viviam na Corte e tinham aquele jornal como lugar de representação de sua cultura e atividade. Entretanto, a fisionomia humanística que conduzia a publicação sofre alterações: nos oito números encontrados na Hemeroteca Digital da Biblioteca Nacional após da morte de Ravara (sete de 1855 e apenas um de 1856) ${ }^{\mathbf{2 6}}$, encontram-se de um lado artigos sobre pianistas, teatro lírico e dramático, poesias, mas também notícias sobre epidemias, política, variedades, anúncios publicitários e sobre personagens da vida social da Corte. Sem faltar a novidade das imagens e caricaturas litografadas de Sébastien Auguste Sisson, que trouxeram para o jornal um caráter mais ilustrativo e crítico, seguindo a tendência de outros periódicos da época. Dos tempos de Ravara, preservou-se o dever de noticiar e criticar as encenações do teatro lírico na Corte, coluna presente em quase todos os números.

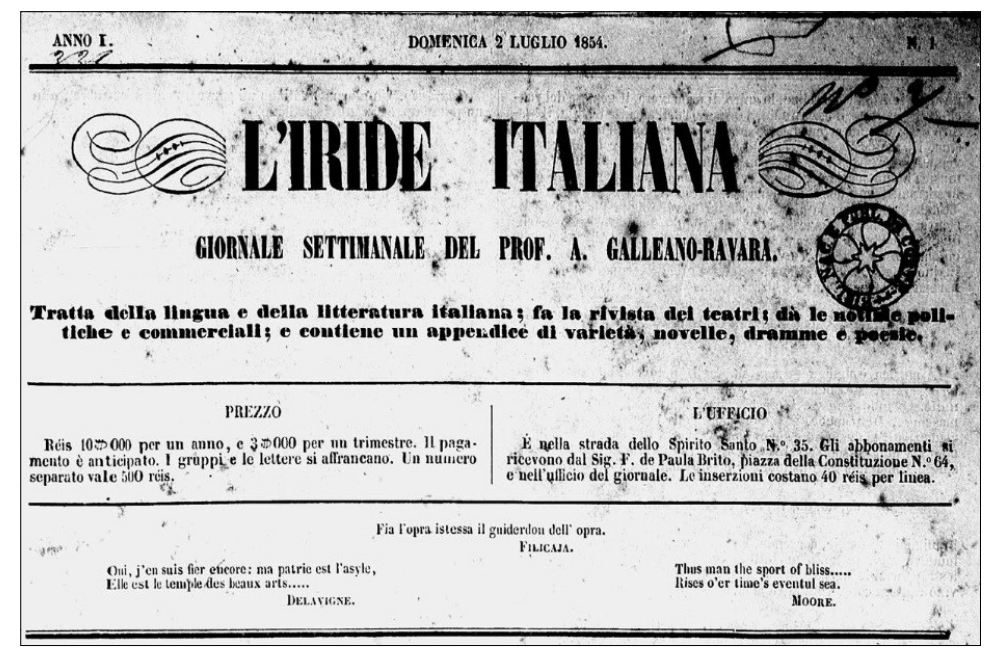

Figura 7: Cabeçalho do número 1, ano I, de L'Iride Italiana

Fonte: L'Iride Italiana, 2/07/1854

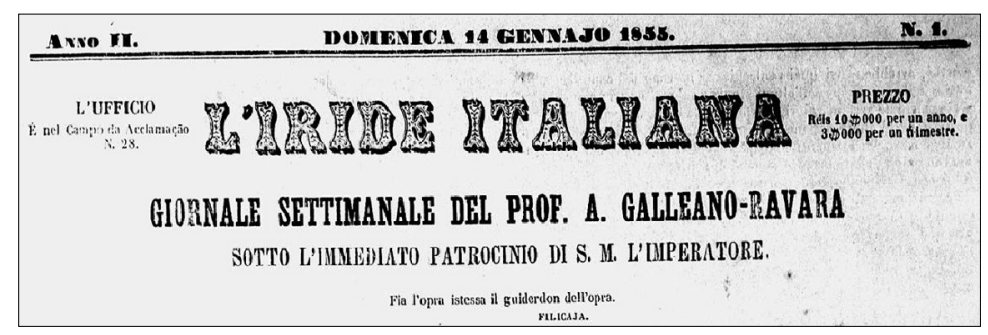

Figura 8: Cabeçalho dos números 1, 2 e 3 de 1855, ano II de L'Iride Italiana

Fonte: L'Iride Italiana, 14/01/1855 


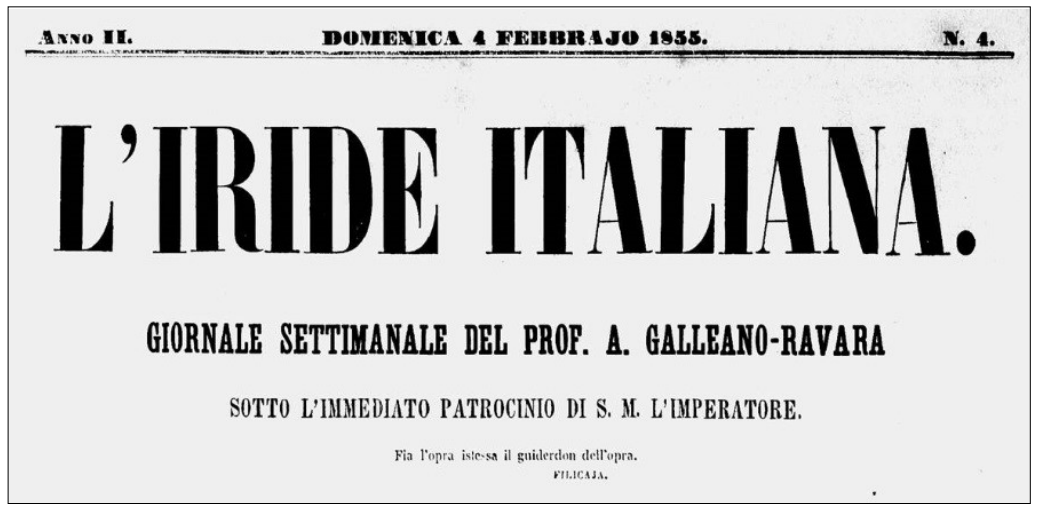

Figura 9: Cabeçalho dos números 4 ao 15 de 1855, ano Il de L'Iride Italiana Fonte: L'Iride Italiana, 4/02/1855

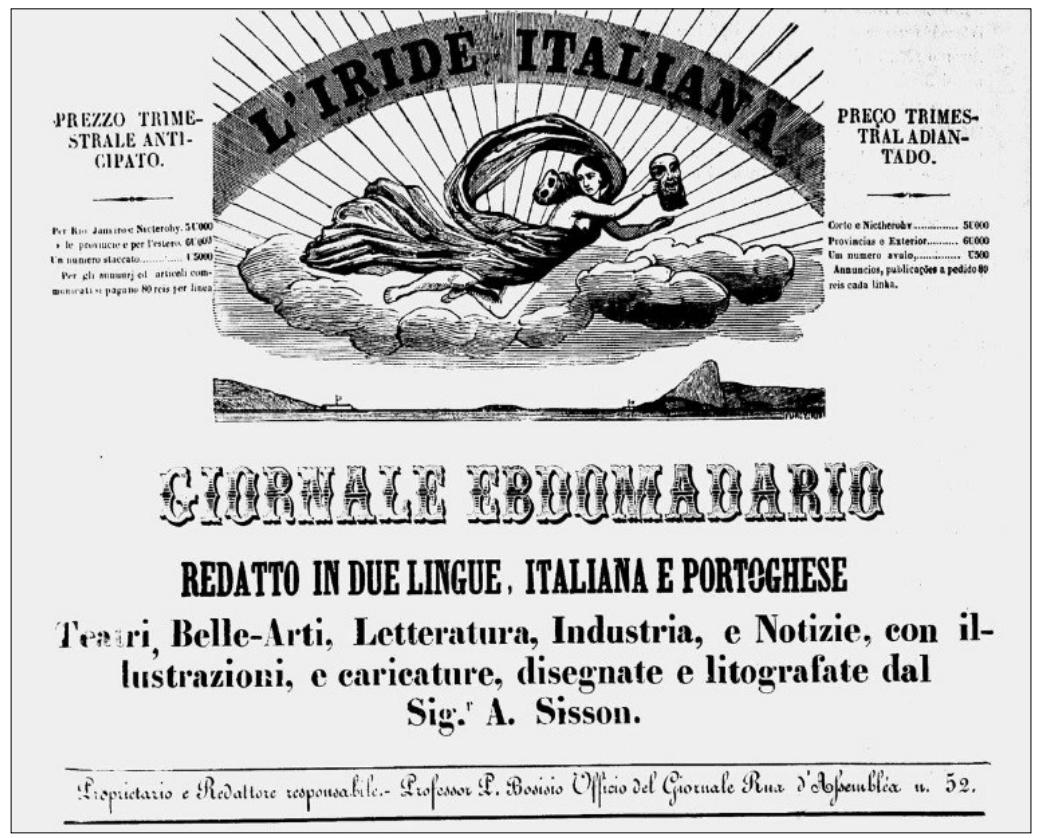

Figura 10: Cabeçalho do número 16 de L'Iride Italiana, ano II, com o nome do novo proprietário e mantido até o final da publicação.

Fonte: L'Iride Italiana, 4/10/1855 
Dadas as diferenças de propostas e o curto período em que L'Iride Italiana ainda sobreviveu depois da ausência do fundador, nota-se que o auge da publicação se concentra no fiador discursivo identificado por Alessandro Galleano Ravara, e que posteriormente procurou-se apenas manter a autoimagem de italianidade fundada pelo jornal, conservando-lhe a organização interna do discurso simbólico, mesmo com o enfraquecimento da potencialidade enunciativa da publicação. Do ponto de vista discursivo, Patrick Charaudeau (2007) nos ajuda a compreender que o texto jornalístico ora analisado reflete, por meio de seus aspectos formais e estilísticos, seus processos de produção, além de apresentar pistas para a interpretação das situações enunciativas que encena. Assim, L'Iride Italiana configura-se como um espaço construído pela linguagem, cuja opacidade abre caminhos para leituras particulares e fracionadas: "Se são [mídias] espelhos [...] mostram, cada um à sua maneira, um fragmento amplificado, simplificado, estereotipado do mundo" (CHARAUDEAU, 2007, p. 20). O que queremos afirmar é que a italianidade de L'Iride não poderia ser reproduzida em nenhum outro lugar discursivo e ter o mesmo efeito, a mesma recepção, sem seu locutor/fiador identificado por Alessandro Galleano Ravara, como podemos notar na tentativa de Pietro Bosisio. Galleano Ravara não só a ideou e realizou, mas endossou sua relevância, legitimidade e prestígio em contexto estrangeiro por meio de sua figura pública e de suas relações de sociabilidade. Nesse sentido, além dos instrumentos enunciativos elaborados no jornal, também esta rede, que testemunha e fortalece a estadia de Galleano Ravara na Corte, atesta a validade do discurso de italianidade empreendido por seu jornal. Interessa-nos em L'Iride Italiana, portanto, não a ideia de nacionalidade como instituição (lembremos que a Itália ainda esperaria quase duas décadas para concretizar sua unificação), mas a compreensão sobre a ascensão de uma legitimidade emocional profunda, capaz de gerar convicções irrefutáveis, mesmo que baseadas em dados “imaginados" (ANDERSON, 2008, p. 12), isto é, construídos no interior do discurso sobre a Itália - italianidade - no periódico.

O discurso de L'Iride Italiana, principalmente antes do falecimento de seu fundador e redator Galleano Ravara, dirige seus leitores à participação imaginária de um vivido, permitindo-nos pensar nesse jornal como um instrumento veiculador de um discurso simbólico sobre a cultura e sobre a ideia de nacionalidade italiana no Rio de Janeiro da segunda metade do século XIX. Dessa forma, compreendemos a publicação como um aparato que encena coesão e patrimônio cultural compartilhado e que visa criar uma imagem identitária - italianidade - fora do território europeu. A circulação de L'Iride Italiana sugere, portanto, que essa publicação possui valores histórico e discursivo de importância pontual na história da imprensa brasileira de imigração, como material precursor e propalador das letras italianas e de alta cultura e, sobretudo, de uma italianidade no Rio de Janeiro oitocentista. 


\section{Referências}

ANDERSON, Benedict. Comunidades imaginadas: reflexões sobre a origem e a difusão do nacionalismo. Trad. de Denise Bottman. São Paulo: Companhia das Letras, 2008.

AVELLA, Aniello Angelo. Teresa Cristina de Bourbon: uma imperatriz napolitana nos trópicos 1843-1889. Rio de Janeiro: EdUERJ, 2014.

Teresa Cristina Maria de Bourbon, uma imperatriz silenciada. Anais do XX Encontro Regional de História: História e Liberdade, 2010, s/p. Disponível em:<http://www.anpuhsp.org.br/sp/downloads/CD\%20XX\%20Encontro/PDF/ Autores\%20e\%20Artigos/Aniello\%20Angelo\%20Avella.pdf>

BRANCO, Manuel Bernardes. Portugal e os estrangeiros. Segunda parte. Volume III. Lisboa, Imprensa Nacional, 1895.

CAPPELLI, Vittorio. A belle époque italiana no Rio de Janeiro. Aspectos e histórias da emigração meridional na modernidade carioca. Trad. de Aline Marques, Cecília Maculan Adum e Raphael Salomão Khéde. Niterói, EdUFF, 2015.

CASOLINO, Enzo; MOTTIN, Antonio J. S. Italianos no Brasil. Contribuições na Literatura e nas Ciências: séculos XIX e XX. Porto Alegre, EDIPUCRS, 1999.

CASTELLANI, Arrigo Ettore. Quanti erano gli italofoni nel 1861? Studi linguistici italiani, v. 8, p. 3-26, 1982.

CHARAUDEAU, Patrick. Discurso das mídias. Trad. de Angela M. S. Corrêa. São Paulo: Contexto, 2007.

DE MAURO, Tullio. Storia linguistica dell'Italia unita. Roma, Bari: Laterza, 1991 [1963].

DE STAËL, Germaine. Sur la manière et l'utilité des traductions [1816]. In: ODDONE, Piero (Org.). La Biblioteca italiana. Treviso: Canova, 1975.

SCHWARCZ, Lilia Moritz. As barbas do imperador: D. Pedro II, um monarca nos trópicos. São Paulo: Companhia das Letras, 1998.

TRENTO, Angelo. Imprensa italiana no Brasil: século XIX e XX. Trad. de Roberto Zaidan. São Carlos: EdUFSCar, 2013.

VANNI, Julio Cezar. Italianos no Rio de Janeiro: a história do desenvolvimento do Brasil partindo da influência dos italianos na capital do Império. Niterói: Ed. Comunità, 2000.

\section{Fontes}

L'Iride Italiana. Hemeroteca Digital. Biblioteca Nacional. Disponível em: <http:// memoria.bn.br/docreader/docreader.aspx?bib=714151> 


\section{Notas}

1 Cf. também CASOLINO; MOTTIN, 1999, p. 120 e CAPPELLI, 2015, p.13.

2 L'Iride Italiana, ano I, n. 1, 2 de julho de 1854, p. 1.

3 IIlustração Brasileira, ano II, n. 26, volume III, de 15 de julho de 1877, p. 27.

4 São exemplos os jornais Monitore Italiano (1860), La Gazzeta Italiana del Brasile (1875), I/ Cosmopolita (1884), La Voce del Popolo (1889), entre muitos outros.

5 “Ai miei Lettori”, L'Iride Italiana, ano I, n. 1, 2 julho de 1854, p.1.

6 L'Iride Italiana, ano II , n. 15, 21 de maio de 1855, p.102 [p.2].

7 Cf. Jornal do Commercio, n. 60, de $1^{\circ}$ de março de 1854, p. 4.

8 Cf. Correio Mercantil, ano XI, n. 307, de 8 de novembro de 1854, p. 1.

9 “In un paese straniero dove si sa che vi è un'Italia nella carta geografica, ma dove tutti non sanno come ella sia divisa, dove tutti non sanno che Genovese e Piemontese, Napolitano e Romano, Parmigiano e Lucchese, Fiorentino e Bolognese vuol dire sempre Italiano [...] (Tradução nossa, "Ai miei Lettori”, L'Iride Italiana, ano I, n. 1, 2 julho de 1854, p. 1).

10 "Chi scrive e parla di teatro non basta che sappia solfeggiare l'aria del tenore [...] ma bensì [...] l'essere italiano, almeno sentire come un Italiano, parlare come un Italiano, capire come gl'Italiani” (Tradução nossa, L'Iride Italiana, ano I, n. 1, de 2 de julho de 1854, p. 2).

11 "Conchiudo. Un giornale italiano mi parve una grande mancanza in un paese dove si canti in italiano". L'Iride Italiana, ano I, n. 1, 2 julho de 1854, p. 2.

12 "Oh povera schiava della tua bellezza e dei tuoi incanti! Perché ti va trascinando nella polve e non ti levi genuflessa ad implorare a Dio mercè per la tua persona?" (Tradução nossa, "Carattere e fine principale di questo giornale", L'Iride Italiana, anno I, n. 2, 9 de julho de 1854, p.2).

13 Usamos o termo de Dominique Maingueneau para expressar as relações que o discurso de L'Iride Italiana teria com um conjunto de determinações físicas e psíquicas associadas ao fiador por meio de representações coletivas (MAINGUENEAU, 2008, p. 65).

14 "Parla italiano, dove tu vai; versa il sì dolcissimo della tua Penisola nel grembo della sorella che ella ama [...]" (Tradução nossa, L'Iride Italiana, ano I, n. 1, de 2 de julho de 1854, p. 2).

15 A publicação de Galleano Ravara desde o número 2 de seu primeiro ano de existência já divulgava textos literários de diferentes autores.

${ }^{16}$ L'Iride Italiana, ano I, n. 1, de 2 de julho de 1854, p. 2.

17 Cf. Discurso pronunciado pelo Sr. L. J. de Carvalho e Mello Mattos, sobre a sepultura do professor A. Galleano Ravara, em L'Iride Italiana, ano II, n. 15, de 25 de maio de 1855, p. 2.

18 “No - no! Un altra volta no! - Un inglese sia legislatore o negoziante, il tedesco beva e fumi la pipa, il francese reciti la commedia, e l'italiano canti!... Peccato che questa sola gloria che ne resta non abbia il valore dei trofei di Camillo e di Augusto! - Ma è nostra proprietà... è nostra gloria! - sola, ma grande!... sola, ma incantevole!... sola, ma inalienabile!" (Tradução nossa).

19 "Col talento innegabile che abbiamo noi per ogni genere di erudizione filologica, colle tendenze visibili che possediamo per parlare e scrivere le lingue più volgari e più utili d’Europa, appena troviamo oggi un poco sparsa tra noi la lingua francese" (Tradução e grifo nossos, L'Iride Italiana, ano I, n. 6 , de 6 de agosto de 1854 , p. 2).

20 Correio Mercantil, ano XII, n. 131, 13 de maio de 1855, p. 1. 


\section{Tradução nossa.}

22 A Typographia Americana de José Soares de Pinho (localizada na rua da Alfândega, 210) imprimirá o jornal até o número 15 de 25 de maio de 1855, no qual é anunciada a morte de seu fundador, o professor Alessandro Galleano Ravara. Depois dessa data, será a Typographia Imparcial de M. J. Pereira da Silva Junior (Rua da Carioca, 32) a se ocupar dessa atividade.

23 L'Iride Italiana, ano II, n. 16, 4 de outubro de 1855, p. 1.

24 L'Iride Italiana, ano II, n. 16, 4 de outubro de 1855, p. 2.

25 L'Iride Italiana, ano II, n. 16, 4 de outubro de 1855, p. 1.

26 A Hemeroteca Digital da Biblioteca Nacional tem resguardado apenas o número 24 de 8 de janeiro de 1856, fazendo pressupor que falta ao seu acervo apenas o número 23 , uma vez que a edição de 2 de dezembro de 1855 é designada pelo número 22.

Gisele Batista da SILVA é Doutora em Letras Neolatinas e Literatura Italiana. Professora do Departamento de Letras Neolatinas da Faculdade de Letras da Universidade Federal do Rio de Janeiro. Endereço: Av. Horácio Macedo, 2151, Cidade Universitária, 21941-917 Rio de Janeiro, RJ, Brasil.

Recebido: 02/09/2018

Aceito: 10/06/2019 